\title{
Nursing Now campaign and its impact on nursing education in a federal university
}

\author{
Campanha Nursing Now e seu impacto no ensino da \\ enfermagem em uma universidade federal
}

Nursing Now campaña y su impacto en la educación en enfermería en una universidad federal

\author{
Rúbia Knobeloch dos Santos ${ }^{a}$ \\ Eluiza Macedo ${ }^{a}$ \\ Bárbara Rodrigues Araujo ${ }^{a}$ \\ Ana Amélia Antunes Lima ${ }^{a}$ \\ Graciele Fernanda da Costa Linch ${ }^{a}$ \\ Rita Catalina Aquino Caregnato ${ }^{a}$
}

\section{How to cite this article:}

Santos RK, Macedo E, Araujo BR, Lima AAA, Linch GFC, Caregnato RCA. Nursing Now campaign and its impact on nursing education in a federal university. Rev Gaúcha Enferm. 2021;42(spe):e20200028 doi: https://doi.org/10.1590/19831447.2021 .20200028
- Universidade Federal de Ciências da Saúde de Porto Alegre (UFCSPA). Porto Alegre, Rio Grande do Sul, Brasil.

\section{ABSTRACT}

Objective: To report the actions developed by a group in the Nursing Now campaign and its impact on nursing education. Method: It is an experience report about the execution of the work group formed by nurse professors, nursing academics and master's students at a federal university in Brazil focusing on the Nursing Now campaign, developing actions in the second half of 2019.

Results: The actions developed involve the creation of a work group and the active participation of the group in four major events resulted in the visibility and appreciation of the work developed by the profession.

Conclusion: The organized group promoted actions that had a positive impact inside and outside the University, expanding visibility to the profession and the actions developed. The academic environment, associated to the worldwide mobilization of the campaign, promoted a favorable context for the debate about the valorization of the category and leadership in nursing.

Keywords: Nursing. Teaching. Leadership. Universities.

\section{RESUMO}

Objetivo: Relatar as ações desenvolvidas por um grupo na campanha Nursing Now e o seu impacto no ensino da enfermagem.

Método: Trata-se de um relato de experiência acerca da atuação de um grupo composto por professoras enfermeiras, acadêmicas e mestrandas de uma universidade federal do Brasil para promover a campanha Nursing Now, desenvolvendo ações no segundo semestre de 2019

Resultados: 0 grupo planejou e executou ações educativas promovendo o trabalho realizado pela Enfermagem na academia. A participação ativa do grupo em quatro grandes eventos resultou na visibilidade e valorização do trabalho desenvolvido pela profissão. Conclusão: 0 grupo organizado gerou ações que causaram impacto positivo dentro e fora da universidade, dando visibilidade à profissão e às ações desenvolvidas. 0 ambiente acadêmico, associado à mobilização mundial da campanha, promoveu um contexto favorável para o debate acerca da valorização da categoria e da liderança na enfermagem.

Palavras-chave: Enfermagem. Ensino. Liderança. Universidades.

\section{RESUMEN}

Objetivo: Exponer las acciones desarrolladas por un grupo en la campaña Nursing Now y su impacto en la educación de enfermería. Método: Relato de experiencia sobre el desempeño de un grupo compuesto por profesores, académicos y másteres estudiantes de una universidad federal en Brasil para promover la campaña Nursing Now, en la segunda mitad de 2019.

Resultados: El grupo planificó y llevó a cabo acciones educativas promoviendo el trabajo realizado por enfermería en la academia. La participación active del grupo en cuatro eventos principales resultó en la visibilidad y apreciación del trabajo desarrollado por la profesión.

Conclusión: El grupo organizado generó acciones que tuvieron un impacto positivo dentro y fuera de la Universidad, dando visibilidad a la profesión y las acciones desarrolladas. El entorno académico, asociado con la movilización mundial de la campaña, promovió un contexto favorable para el debate sobre la valorización de la categoría y liderazgo en enfermería.

Palabras clave: Enfermería. Enseñanza. Liderazgo. Universidades. 


\section{INTRODUCTION}

Current nursing, despite its development in the scientific and technological fields, still has an impaired social visibility due to beliefs based on cultural stereotypes, such as subordination to other health professionals ${ }^{(1)}$. Contributing as a barrier factor and affecting how society recognizes the profession, gender issues influence the professional's view of fragility, making nursing empowerment necessary to improve the profession's recognition ${ }^{(2)}$.

To meet the growing development of nursing as a field with a potential to transform reality in health ${ }^{(3)}$, the Burdett Trust For Nursing and the International Nurses Council, in collaboration with the World Health Organization (WHO), created the campaign Nursing Now, in 2018. This worldwide campaign highlights the importance of strengthening and collaborating with local institutions, both in health and education, to outline strategies that provide advances to nursing professionals. The campaign foresees collaborative international and national goals for the valorization and empowerment of nursing, with its peak in 2020, for being considered by WHO as the international year of Nursing due to the celebrations of the bicentenary of Florence Nightingale ${ }^{(4)}$.

In Brazil, the Nursing Now campaign was launched in April 2019, based on the articulation of the Federal Nursing Council (COFEN) with the PAHO/WHO Collaborating Center for the development of Nursing Research, linked to the Ribeirão Preto School of Nursing from USP(5). The international and national goals linked to the campaign Nursing Now aim to increase the visibility and appreciation of nurses, highlighting the importance of the profession for the qualification of health services. One of the pillars of the campaign is to attract more men and women to develop the art of care, as there are places where nursing is scarce and has numerous health problems, showing the negative impact caused by the absence of the professional nurse, who works in preventing health problems in addition to health promotion and recovery ${ }^{(4-6)}$.

One of the campaign's national goals is to invest both in strengthening education and in the development of nursing professionals, with a focus on leadership. By encouraging the development of nursing from the perspective of team leadership, coordination, teaching, research and care, the campaign will contribute to raising the profile and status of nurses, preparing them to assume leadership positions, in order to expand their influence in discussions involving social issues that affect health systems, also obtaining the desired recognition ${ }^{(2-3)}$.

In the international context, the importance of education for leadership exercised by health professionals in the 21st century is discussed. The authors associate the exercise of high-quality leadership with progress in improving health and health systems., including changing health care models to be person-centered ${ }^{(3,7)}$. In this perspective, the nurse is a strategic professional for the development of health and, consequently, teaching should encourage leadership in group relations and coordination ${ }^{(8)}$ to meet the population's health needs ${ }^{(3)}$.

Given the relevance of the Nursing Now campaign, the undergraduate and graduate courses in Nursing at a federal university that is entirely dedicated to the health field, strongly joined the campaign after it was made official in Brazil, creating a working group (WG) to develop actions, publicize actions performed by nursing as a profession, and encourage the leadership among nursing students. The triggering question for this report was: what are the activities developed by a working group from a public university to collaborate with the Nursing Now campaign? The objective is to report the actions developed by a group in the Nursing Now campaign and its impact on the teaching of nursing.

\section{METHOD}

This is an experience report on the creation and performance of a WG aimed at disseminating the Nursing Now campaign at a Brazilian federal university specialized in the health area, located in the southern region of Brazil, with approximately 2,625 students enrolled in the 16 courses and 2,693 students enrolled in 94 postgraduate courses in 2019(9).

The WG consisted of seven teachers, eleven nursing students (from the first to the fifth year) and two master's nurses from the Professional Master's Program in Nursing. Four actions were developed with themes related to commemorative dates or events in the health area, from September to December 2019.

\section{口 RESULTS}

\section{Creation of the Working Group Nursing Now}

The creation of the WG started in June 2019, with the selection of students based on enrollment in the activities of the academic nursing week at the University, where the objectives proposed by the Nursing Now campaign were presented, aiming to raise awareness and engage academics. For the selection, pro-activity, the connection with teaching, research and extension projects, in addition to leadership skills and teamwork were considered.

The WG started the work by holding meetings to define actions in line with the campaign's objectives and the 
development of leadership, and also creating fan pages on social media. The themes for the development of actions were allusive to commemorative dates, or events in the health area, namely: September: "patient safety," October: "Breast cancer prevention,"November: related to research and graduate studies, and December: launch of the Nursing Now campaign in Rio Grande do Sul, in partnership with COREN-RS.

\section{Action at the University: Patient Safety workshops}

The initial theme chosen to publicize the Nursing Now campaign was "patient safety," since September 17 is considered by WHO to be the "world patient safety day."Teaching activities developed during the university's Congress were planned, in the form of two workshops, and the Nursing Now campaign banner was created for dissemination.

90 academics from different courses in the health field participated in the workshops, who received a hand hygiene kit $(\mathrm{HH})$ with hand sanitizer and guidance folders on $\mathrm{HH}$ as a courtesy. The workshop was developed in the following stages: 1) presentation of the six patient safety goals by the WG students, with the help of a poster, 2) application of a virtual game with 10 objective questions of multiple choice, promoting interactivity with the participants, with the purpose of evaluating previous knowledge, discussing each question and commenting on the answers with immediate feedbacks, 3) presentation of clinical cases in small groups, for the identification of safety goals in routines of health establishments, and 4) evaluation of activities.

At the end of one of the workshops, the students of the WG produced a video with the support of six visual symbols, to assist in memorizing the six international goals of patient safety, being disseminated on the WG's social networks, obtaining 518 views.

\section{WG action during Pink October: experience, empowerment and the art of caring}

In October, educational activities were directed to the Pink October event: experience, empowerment and the art of caring, promoted by the Gynecology and Obstetrics and Cancer Leagues. The WG academics developed actions for the prevention of breast cancer, using breast molds (with and without the presence of nodules), demonstrating the technique of breast self-examination, while emphasizing the importance of mammography for early diagnosis. This activity provided the interaction of academics with the public, articulating knowledge for the promotion of women's health through health education. Graphic material was distributed, pink ribbons and a message board to support women undergoing cancer treatment.

\section{WG action at the Professional Nursing Master's Symposium}

In November, the Graduate Program in Nursing (PPGEnf) promoted an event for the dissemination of scientific productions and products of professional master's programs in nursing in Rio Grande do Sul. Recognizing the importance of the event for promoting the dissemination of nursing scientificity and engagement in the visibility of the profession, the WG inserted the academics in activities regarding event organization, encouraging them to develop leadership. During the event, the organizers emphasized the participation of the WG as a driving force for the formation of a leadership mentality and granted space to present the Nursing Now campaign and the WG.

The presentation of the "Map of Innovations" of the Federal Nursing Council (COFEN), one of the products developed in the PPGEnf of the University, is a relevant product for the dissemination of the profession and its empowerment.

\section{WG action at the Launch of the Nursing Now Campaign in Rio Grande do Sul}

On December 6, 2019, the university hosted the Nursing Now RS campaign launch, an event promoted by the Regional Nursing Council of Rio Grande do Sul (COREN-RS), when the members of the WG welcomed nursing professionals from Rio Grande do Sul and disclosed the group's performance.

\section{DISCUSSION}

The creation of the WG and its actions had an internal and external impact on the university, in nursing and in other courses in the health field. In the academic field, as a means of promoting professional training, the actions mobilized nursing professors and students to grant visibility to the campaign and the development of leadership for teamwork. Thus, the WG was aligned with one of the goals proposed in the campaign: "To invest in strengthening education and developing nursing professionals with a focus on leadership"(10-11).

The inclusion of students from different periods of the nursing course in the WG provided a space for discussions about the planning and development of actions, stimulating collective work, creativity in the production of material and the execution of actions, instigating leadership skills as educators in health. These aspects are attributed to the nurse in 
the exercise of their work, corroborating the development of skills during academic training, in order to form a critical, reflective, autonomous nurse, aware of their transforming power in the health system ${ }^{(3,8)}$. The understanding and execution of leadership by students during graduation remains a challenge for the teaching of nursing, being one of the competencies required by the National Curriculum Guidelines for Undergraduate Nursing Courses ${ }^{(8)}$. In order to minimize this challenge, the teaching of leadership can be developed based on active methodologies, such as games and clinical cases, that stimulate critical and reflective thinking, with an emphasis on solving challenges and problems ${ }^{(10)}$. Based on this, the WG's interventions were developed focusing on autonomy and criticism, in addition to learning distinct knowledge, based on methodologies that involved academics as active participants in their learning process, aiming to stimulate leadership, criticism and reflection.

The external impact of the actions developed by the WG was to promote the profession's social visibility. Thus, the WG decided on the creation of pages for the dissemination of actions on social networks, which constitute new forms of communication, resulting from advances in the area of information technology and add importance to campaigns such as Nursing Now, whose proposed goals aim at professional empowerment and the visibility of the profession in the global context. The Nursing Now WG promoted the profession's social marketing by sharing photos, videos and events alluding to the campaign. A profession's visibility requires strategies that allow its recognition, and professional, personal and social marketing are all means to achieve this purpose. Within several types of marketing, choice was made for social marketing because it is a strategy used in the health field since the 1970s to disseminate campaigns, causes or ideas ${ }^{(12)}$.

The inclusion of social networks as promoters of the dissemination of the actions developed by the WG helped with the profession's social marketing, in publicizing actions, behaviors and guidance on the themes involving the health fields. Equally relevant, in addition to the in-person actions developed, social networks contribute to promote and expand the visibility of nursing, reaching a larger, external audience to the university, instigating society to get to know the protagonism of nurses in different health scenarios.

\section{$\square$ CONCLUSION}

The Nursing Now campaign promoted the creation of a work group with nursing professors and students from different periods of the course, in addition to graduate students. The insertion of nursing students in the work group contributed to strengthening the education of future nurses, by encouraging the exercise of leadership through teamwork and the planning and development of the proposed actions, aligned with the promotion of the population's health. The meetings held by the working group in order to jointly plan the actions performed represented spaces for the discussion of health needs, the challenges of being a nurse, the valorization of nursing and the role of the profession. The academic environment is strategic for the execution of educational actions and conducive to debating and learning about leadership, a theme that constitutes one of the national goals proposed by the Nursing Now campaign. The limitation of the study is the lack of an expanded discussion about the campaign with the other students of the course and the nursing teams of the partner institutions, in order to strengthen the reflection of the nursing praxis and the meaning of the goals for the protagonism and empowerment of the profession today.

\section{REFERENCES}

1. Avila LI, Silveira RS, Lunardi VL, Machado GFF, Mancia JR, Silveira JT. Implications of the visibility of professional nursing practices. Rev Gaúcha Enferm. 2013;34(3):102-9. doi: https://doi.org/10.1590/S1983-14472013000300013

2. Donoso MTV, Donoso MDV. 0 cuidado e a enfermagem em um contexto histórico. Rev Enf UFJF. 2017 [cited 2020 Jan 28];2(1):51-5. Available from: https://periodicos.uff.br/index.php/enfermagem/article/view/3841

3. Cassiani SHB, Fernandes MNF, Lecorps K, Silva FAM. Leadership in nurse: why should we discuss it? Rev Panam Salud Publica. 2019;43:e46. doi: https://doi. org/10.26633/RPSP.2019.46

4. Cassiani SHB, Lira Neto JCG. Nursing perspectives and the "Nursing Now" campaign. Rev Bras Enferm. 2018;71(5):2351-2. doi: https://doi. org/10.1590/0034-7167.2018710501

5. Silva MCN. 0 Nursing Now desembarca no Brasil para evidenciar a força e a capacidade da enfermagem [editorial]. Enferm Foco. 2019;10(1). doi: https:// doi.org/10.21675/2357-707X.2019.v10.n1.2322

6. Mendes IAC. Agora sim!!! Lançamento da campanha Nursing Now Brasil [editorial]. Enferm Foco. 2019;10(2):1-3. doi: https://doi.org/10.21675/2357707X.2019.v10.n2.2331

7. Hewison A. Leading nursing beyond 2020: the challenge and the opportunity. J Nursing Manag. 2020;28(4):767-70. doi: https://doi.org/10.1111/jonm.13022

8. Amestoy SC, Trindade LM, Silva GTR, Santos BP, Reis VRSS, Ferreira VB. Leadership in nursing: from teaching to practice in a hospital environment. Esc Anna Nery. 2017;21(4):e20160276. doi: https://doi. org/10.1590/2177-9465-ean-2016-0276

9. Universidade Federal de Ciências da Saúde de Porto Alegre (BR) [Internet]. Porto Alegre: UFCSPA;2020 [cited 2020 Jul 27]. UFCSPA em Tempo Real. Available from: https://www.ufcspa.edu.br/index.php/tempo-real

10. Caveião C, Peres AM, Zagonel IPS. Metodologias para 0 ensino da liderança na graduação em enfermagem: revisão integrativa. Rev Saúde Desenv. 2018 [cited 2020 Jan 28];12(13):234-55. Available from: https://www.uninter.com/ revistasaude/index.php/saudeDesenvolvimento/article/view/1009/565 
11. Borges TS, Alencar G. Metodologias ativas na promoção da formação crítica do estudante: 0 uso das metodologias ativas como recurso didático na formação crítica do estudante do ensino superior. Cairu Rev. 2014 [cited 2020 Jan 28];3(4):119-4. Available from: https://www.cairu.br/revista/ arquivos/artigos/2014_2/08\%20METODOLOGIAS\%20ATIVAS\%20NA\%20
PROMOCA0\%20DA\%20F0RMACA0\%20CRITICA\%20D0\%20ESTUDANTE.pdf

12. Mendes IAC, Trevisan MA, Mazzo A, Godoy S, Ventura CAA. Marketing profissional e visibilidade social na enfermagem: uma estratégia de valorização de recursos humanos. Texto Contexto Enferm. 2011;20(4):788-95. doi: https:// doi.org/10.1590/S0104-07072011000400019

\section{- Authorship contribution:}

Conceptualization - Rúbia Knobeloch dos Santos, Eluiza Macedo, Bárbara Rodrigues Araujo, Ana Amélia Antunes Lima, Graciele Fernanda da Costa Linch, Rita Catalina Aquino Caregnato.

Data curation - Rúbia Knobeloch dos Santos, Eluiza Macedo, Bárbara Rodrigues Araujo, Rita Catalina Aquino Caregnato.

Formal analysis - Rúbia Knobeloch dos Santos, Eluiza Macedo, Bárbara Rodrigues Araujo, Ana Amélia Antunes Lima, Graciele Fernanda da Costa Linch, Rita Catalina Aquino Caregnato.

Acquisition of financing - not applicable.

Research - Rúbia Knobeloch dos Santos, Eluiza Macedo, Bárbara Rodrigues Araujo, Ana Amélia Antunes Lima, Graciele Fernanda da Costa Linch, Rita Catalina Aquino Caregnato.

Methodology - Rúbia Knobeloch dos Santos, Eluiza Macedo, Bárbara Rodrigues Araujo, Ana Amélia Antunes Lima, Graciele Fernanda da Costa Linch, Rita Catalina Aquino Caregnato.

Project management - Rúbia Knobeloch dos Santos, Rita Catalina Aquino Caregnato.

Resources - Rúbia Knobeloch dos Santos, Eluiza Macedo, Bárbara Rodrigues Araujo, Ana Amélia Antunes Lima, Graciele Fernanda da Costa Linch, Rita Catalina Aquino Caregnato.

Software - does not apply.

Supervision - Rúbia Knobeloch dos Santos, Rita Catalina Aquino Caregnato.

Validation - Rúbia Knobeloch dos Santos, Ana Amélia Antunes Lima, Graciele Fernanda da Costa Linch, Rita Catalina Aquino Caregnato.

Visualization - Rúbia Knobeloch dos Santos, Eluiza Macedo, Bárbara Rodrigues Araujo, Ana Amélia Antunes Lima, Graciele Fernanda da Costa Linch, Rita Catalina Aquino Caregnato.

Writing - original draft - Rúbia Knobeloch dos Santos, Eluiza Macedo, Bárbara Rodrigues Araujo, Ana Amélia Antunes Lima, Graciele Fernanda da Costa Linch, Rita Catalina Aquino Caregnato. Writing - review and editing - Rúbia Knobeloch dos Santos, Eluiza Macedo, Bárbara Rodrigues Araujo, Ana Amélia Antunes Lima, Graciele Fernanda da Costa Linch, Rita Catalina Aquino Caregnato.

\section{- Corresponding author:}

Rúbia Knobeloch dos Santos

E-mail: rubiaknobeloch@gmail.com

\section{Associate editor:}

Dagmar Elaine Kaiser 